\title{
Notch signaling in pediatric soft tissue sarcomas
}

\author{
Rossella Rota ${ }^{1 *}$, Roberta Ciarapica ${ }^{1}$, Lucio Miele ${ }^{2}$ and Franco Locatelli ${ }^{1,3}$
}

\begin{abstract}
Pediatric soft tissue sarcomas are rare tumors of childhood, frequently characterized by specific chromosome translocations. Despite improvements in treatment, their clinical management is often challenging due to the low responsiveness of metastatic forms and aggressive variants to conventional therapeutic approaches, which leads to poor overall survival. It is widely thought that soft tissue sarcomas derive from mesenchymal progenitor cells that, during embryonic life, have developed chromosomal aberrations with de-regulation of the main pathways governing tissue morphogenesis. The Notch signaling pathway is one of the most important molecular networks involved in differentiation processes. Emerging evidence highlights the role of Notch signaling de-regulation in the biology of these pediatric sarcomas. In this review, we present an outline of recently gathered evidence on the role of Notch signaling in soft tissue sarcomas, highlighting its importance in tumor cell biology. The potential challenges and opportunities of targeting Notch signaling in the treatment of pediatric soft tissue sarcomas are also discussed.
\end{abstract}

Keywords: soft tissue sarcoma, Notch, mesenchymal cells, $y$-secretase, Synovial sarcoma, Ewing sarcoma, Rhabdomyosarcoma

\section{Review}

\section{Differences between adult and pediatric tumors}

What makes the majority of pediatric tumors different from adult ones is their 'embryonal' origin. An inflammatory microenvironment and/or the age-dependent accumulation of genetic mutations and epigenetic alterations have a well-recognized importance in the pathogenesis of adult tumors. Conversely, in tumors arising in newborns and children, de-regulation of developmental pathways

\footnotetext{
* Correspondence: rossella.rota@opbg.net

'Department of Oncohematology, Ospedale Pediatrico Bambino Gesù, IRCCS, Piazza Sant'Onofrio 4, Roma, 00165, Italy

Full list of author information is available at the end of the article
}

during embryonic life seems to play a major role. This view is also supported by the observation that the most aggressive pediatric tumors frequently harbor chromosomal translocations involving genes that regulate embryogenesis and tissue determination.

Several critical developmental pathways have been involved in pediatric tumor biology such as Hedgehog (Hh), Wnt and, more recently, Notch signaling. All are crucial regulators of differentiation, balancing proliferation versus differentiation and defining the tissue lineage commitment of precursor cells. Mutations of molecular components of Notch signaling have been involved in different genetic disorders [1-3]. As of this writing, Notch signaling de-regulation is recognized as a feature of several types of adult cancers [4-9]. However, the first evidence that human Notch1 is a proto-oncogene came from a predominantly pediatric malignancy, acute T-cell leukemia (T-ALL) [10]. Notch1 was subsequently shown to be the most commonly mutated oncogene in T-ALL [11]. Over the past few years, growing evidence also points to a role of abnormalities of Notch signaling in pediatric solid tumors. Recently, Notch signaling has been investigated, by our and other groups, in tumors of childhood that are thought to originate from mesenchymal progenitors, that is, soft tissue sarcomas (STS). The unresponsiveness to current conventional therapies observed for metastatic STS and the higher relapse rate seen for the translocation-bearing aggressive histological subtypes, together with the significant adverse effects of current therapy in young people, prompted the research community to seek new markers/targets for treatment of these tumors. In this context, therapies aimed at modulating the Notch signaling pathway are considered promising for tailored approaches. Notch inhibitors are currently being evaluated in a growing number of clinical trials, mainly in adults.

The present review aims at summarizing recent insights on the role of Notch signaling in pediatric STSs, highlighting the context/tumor-dependent role of specific Notch components. Current therapeutic strategies aimed at inhibiting Notch signaling and their potential pros and cons are discussed. 
Soft tissue sarcomas: a developmental defect?

Pediatric STSs consist of a group of heterogeneous malignancies of mesenchymal origin that accounts for $1 \%$ of all human cancers and up to $15 \%$ of all pediatric tumors (Figure 1). STSs represent a clinical challenge because, due to their infiltrating potential, they are generally difficult to eradicate surgically and, especially when metastatic at diagnosis, are unresponsive to conventional therapy $[12,13]$.

Our growing knowledge of the molecular pathogenesis of STS suggests new antitumor treatments based on targeted molecular strategies. Consistent with the hypothesis that aberrant embryonic developmental molecular pathways may be involved in the development of pediatric STS, there is evidence that clonal cell populations harboring only one specific chromosomal translocation are maintained throughout tumor progression [14]. Is it possible that mesenchymal progenitor cells (MSC) that undergo a physiological cellular maturation become neoplastic at discrete stages of differentiation? Evidence for such a mechanism has been reported for Ewing sarcoma (ES) [15,16] and rhabdomyosarcoma (RMS) [17]. A high histological differentiation degree in STSs correlates with a good prognosis. It is conceivable that what determines the clinical failure of STS treatment is the presence of small populations of highly undifferentiated cells that have tumor-initiating potential and self-renewal capacity, and that are largely unresponsive to chemotherapy $[17,18]$. In this context, blocking developmental pathways involved in the maintenance of the stem cell compartment, such as the Notch pathway, may be an attractive strategy to improve the clinical management of STS.

Indeed, recently we and other groups have shown preclinical evidence that Notch signaling modulation has

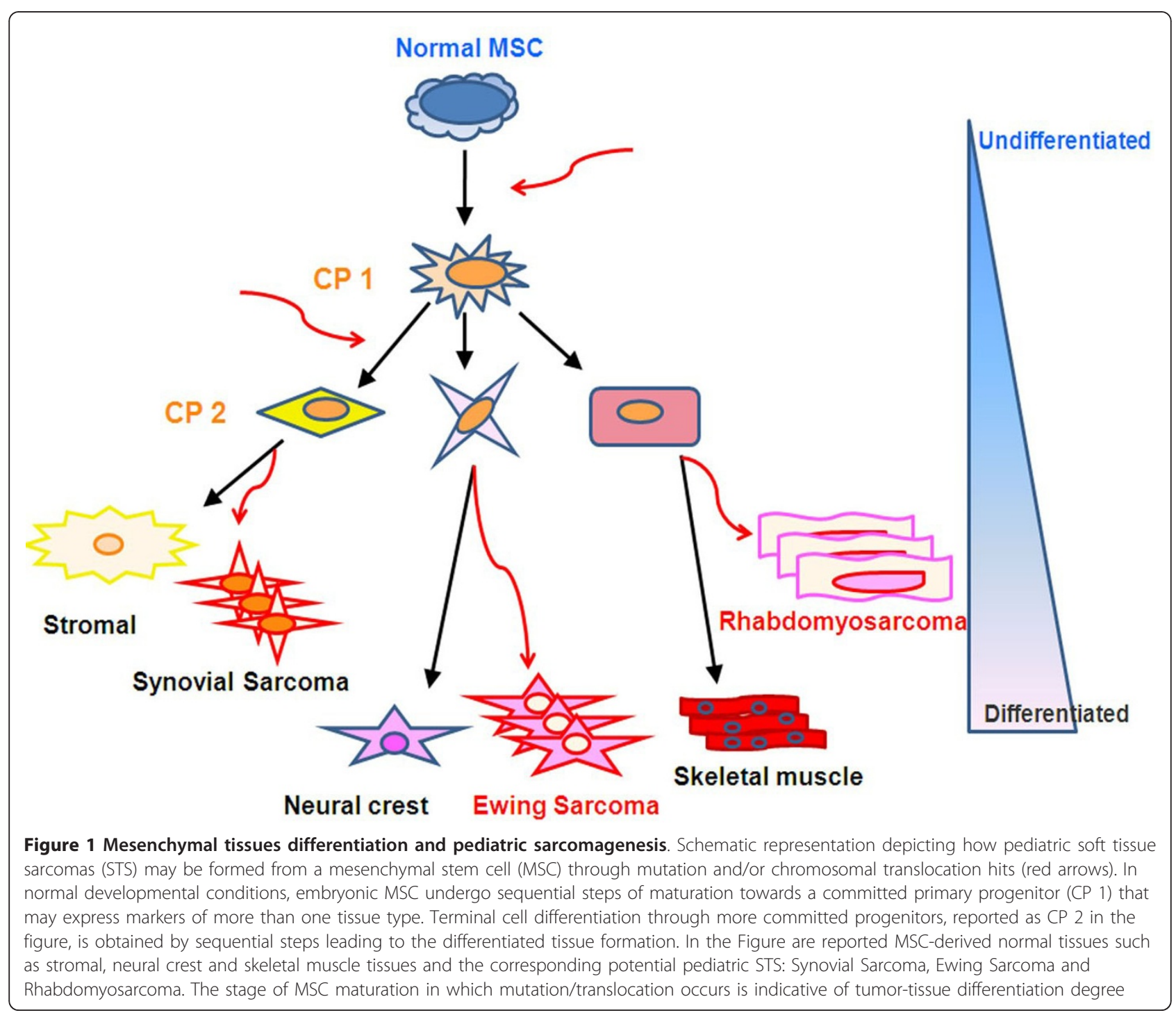


anti-tumor effects in the most common pediatric STS such as ES and RMS.

\section{Notch signaling pathway}

The Notch signaling is a close range cell-to-cell communication system that allows the crosstalk between different contiguous cellular compartments in the embryo and in post-natal life. Notch signals regulate the determination/maintenance of cellular identity. In mammals, the Notch signaling pathway consists of four trans-membrane receptors, Notch 1 to Notch4, encoded by homologous but different genes (reviewed in $[4,19,20]$ ). Notch receptors include an extracellular region, a trans-membrane region, and an intracellular domain (ICD) [20]. The Notch receptors are activated upon binding to transmembrane ligands of the Delta-Serrate/Jagged families. Humans and rodents express at least three Delta-like (DLL) ligands, 1, 3 and 4 and two Serrate/Jagged family ligands, JAG1 and 2. Notch ligands are expressed on the surface of cells contiguous to receptor-expressing cells. Ligand binding to a Notch receptor results in two sequential receptor cleavages operated by specific proteases, an ADAM protease at the cell surface and $\gamma$-secretase in the transmembrane domain. Cleavage by $\gamma$-secretase (GSI) releases Notch ICD into the cytoplasm. The Notch ICD is the 'active' fragment that migrates to the nucleus. In the nucleus, Notch ICD replaces the co-repressor complex on a DNA-binding transcription factor, CSL/RBP-Jk (CBF1/ $\mathrm{RBPj} \kappa / \mathrm{Su}(\mathrm{H}) / \mathrm{Lag}-1)$. The Notch-CSL complex triggers the transcription of Notch target genes. These include, among others, the basic helix-loop-helix (bHLH) transcription factors of the Hes and Hey (HESR) families working as transcriptional repressors [21]. The Notch ICD once released into the cytoplasm can be post-translationally modified and/or can interact with several molecules that either amplify or dampen Notch signaling [19]. These include, for example, prolyl isomerase Pin1 [22] and Nemo-like kinase NLK [23]. In particular, the C-terminal proline, glutamic acid, serine and threonine degradation (PEST) domain is a target for ubiquitylation favoring ICD proteolytic degradation (reviewed in $[4,19,20]$ ). The complexity of the Notch system is further enhanced by noncanonical signaling. This includes cis-inhibition by Notch ligands expressed on the same cell as the receptors, Notch activation by non-canonical ligands, ligand-independent Notch activation and CSL-independent signaling [24]. Cytoplasmic Notch signaling mediated by the mTOR complex has been demonstrated in some cells, such as T regulatory cells [25]. The choice among these different manners of activation and the expression of specific Notch receptor paralogs and/or ligands during a specific cellular program is context-, cell- and time-dependent during both embryogenesis and post-natal life. Moreover, Notch paralogs expressed in the cell can behave in opposite manners
[19]. Further levels of regulation are obtained before cell membrane localization of Notch receptor molecules through the glycosylation of the Notch extracellular domain in the Golgi complex by enzymes such as POFUT-1 (O-fucosyltransferase) and Manic, Lunatic and Radical Fringe (MFNG, LFNG and RFNG, respectively, O-fucosyl, $\beta$-1-3 N-acetylglucosaminyltransferases), which affects its affinity and binding to specific ligands. For instance, LFNG-mediated modifications in most cells reduce the affinity for Jagged family ligands but not Delta family ligands. Although this complexity may appear daunting, it offers multiple opportunities to modulate signal intensity at different levels or through different Notch receptors, thus acting on different aspects of tumor progression. One of the most studied inhibitory approaches is the use of GSI, first investigated in Alzheimer's disease, that prevent the cleavage of Notch receptors and subsequent Notch signaling activation. GSIs are being, or have been, investigated in several anti-cancer clinical trials.

Contrary to what is observed in T-ALL that often is triggered by a Notch1 receptor mutation, in solid cancers, few genetic alterations have been found so far in Notch signaling components. In many solid tumors, Notch signaling de-regulation may be a consequence of the primary oncogenic mutation(s) rather than the main causative event. However, in many such malignancies Notch signaling seems to play a general role in the maintenance of tumor phenotype and especially in the survival and self-replication of tumor-initiating cells. Additionally, non-cell autonomous roles of Notch signaling in tumor stroma, in endothelial cells and in the immune system can also contribute to tumor survival and recurrence (reviewed in [26]). In some situations, individual Notch paralogs have been found to have tumor-suppressive properties. The best-documented example is the role of Notch1 in squamous epithelia [27]. In some cases, these effects as well as non-cell autonomous result from disruption of epithelial barrier functions in the absence of Notch, which in turn promotes chronic dermal inflammation that predisposes to tumorigenesis [28].

\section{Notch signaling in synovial sarcoma}

Synovial sarcoma (SS) develops in adolescents and young adults and has an aggressive behavior with high metastatic potential [29]. It accounts for $7 \%$ to $10 \%$ of all STS [30]. SS was initially termed 'synovial' because it is found in the soft tissue adjacent to joints of young adult patients and resembles developing synovial tissue. However, SS is frequently observed in extra-synovial locations such as kidney, lung and heart and recent findings suggest its derivation from MSCs [30,31]. The majority of SSs harbors the chromosomal translocation $\mathrm{t}(\mathrm{X} ; 18)$ (p11; q11) between the Synovial Sarcoma translocation, chromosome 18 gene (SS18, previously SYT) on chromosome 
$18 \mathrm{q} 11$ and either Synovial Sarcoma, $\times$ breakpoint 1, 2 or 4 (SSX1, SSX2, or SSX4, respectively) genes on chromosome Xp11. The SS18-SSX fusion onco-proteins contain the transcriptional activation domain of SS18 fused to the repressor domain of SSX but lack a DNA-binding domain [32]. They form non-physiologic protein complexes that are absent in normal cells. The identification of their target genes is difficult because of the lack of direct binding to DNA. Expression of SS18-SSX oncoproteins is necessary and sufficient to cause malignant transformation. Indeed, rat fibroblasts expressing exogenous SS18-SSX showed a transformed behavior [32]. Conditional overexpression of SS18-SSX2 in transgenic mice results in SS formation but only when the transgene is expressed in mesenchymal-derived myogenic progenitors [29]. Finally, knockdown of SS18-SSX in SS cell lines induced loss of differentiation abilities into mesenchymal-derived tissue, strongly supporting the hypothesis of a MSC origin for this tumor [30].

To date, a direct mechanistic link between SS biology and Notch signaling has not been clearly demonstrated; however, some findings suggest that Notch signaling could be involved in SS (Table 1). In a pioneering study by Francis and colleagues, gene expression analysis was carried out in a large set of STS, among which were 31 SS primary samples [33]. In an effort to identify diagnostic marker genes that could discriminate among the different subtypes of STS, a very highly heterogeneous group of tumors, 4,000 genes were found to be differentially expressed in SS. These included the major developmental pathways such as $\mathrm{Hh}$, Wnt, tumor growth factor $\beta$ (TGF $\beta$ ), chromatin remodeling complexes and Notch. In particular, Notch1, JAG1 and the transducin-like enhancer (TLE) of split genes were up-regulated in SS. TLE genes are known Notch targets, and encode a family of four master transcriptional regulators (TLE1 to 4), highly conserved among species. TLE genes are expressed during embryogenesis and work in concert with the Wnt/ $\beta$ catenin pathway, known to be prooncogenic in SS [34,35]. In particular, the over-expression of TLE1 appears to be a reliable marker to discriminate SS from other types of STS, independently from the type of SSX fusion and the degree of tumor differentiation [36-38], although a study showed TLE1 to be expressed also in other non-synovial STS [39]. TLE1, an evolutionarily conserved Notch effector, mediates the anti-differentiation functions of Notch signaling in neuronal cells. There, it works as an important co-repressor by facilitating the binding of HES proteins (direct Notch transcriptional targets) to promoters of target genes to allow gene repression [40]. Therefore, the over-expression of TLE1 in SS may mediate similar effects of Notch in SS and deserves further investigation.

Very recently, a functional role for TLE1 in SS pathogenesis has emerged from the observation that SSX18-SSX proteins behave as a scaffold to bridge TLE1 and the DNA-binding protein activating transcription factor 2 (ATF2) [41]. The physiologic role of ATF2 as a master transcriptional activator is reversed in the non-physiologic, pro-oncogenic complex SS18-SSX/TLE1/ATF2. The latter recruits histone deacetylases (HDACs), and retaines the co-repressor ability of TLE1 to repress the transcription of ATF2-induced genes, such as cell cycle regulator and apoptotic genes, resulting in tumor cell survival. Conversely, disruption of the SS18-SSX/TLE1/ATF2 complex by silencing of SS18-SSX led to cell cycle arrest and cell death. One of the targets repressed by the oncogenic complex SSX/ TLE1/ATF2 is the Early Growth Response-1 (EGR1) gene, a tumor suppressor gene that regulates cell growth and differentiation. EGR1 was previously demonstrated by the same authors to be maintained at low levels in SS by the interaction of SS18-SSX with Polycomb proteins from the Polycomb Repressor Complex 2 (PRC2), such as Enhancer of Zeste Homolog 2 (EZH2) and PRC1, such as BMI1 polycomb ring finger oncogene (BMI1) [42]. The knockdown of TLE1 increased the transcription of EGR 1 and decreased the levels of histone $\mathrm{H} 3$ trimethylation on Lysine 27 (H3K27me3), which is a mark of EZH2 activity [41]. Taken together, these findings suggest that TLE1, a known effector of Notch signaling, plays a fundamental role in the SS18-SSX epigenetic regulation of gene expression in SS. Future investigations could elucidate whether TLE1 has the same function in normal developing cells.

Interestingly, when EGR1 was re-expressed by a gain-offunction approach in SS cells, it induced the transcription of Phosphatase and tensin homolog deleted in chromosome 10 (PTEN) gene, which, in turn, favored the pro-apoptotic effects of HDACs inhibitors [42]. PTEN has been reported as mutated in one out of four samples from SS patients [43]. A link between PTEN expression and Notch signaling has been demonstrated in different tumor contexts. PTEN has been shown to be down-regulated after Notch1 ICD over-expression in hypoxic mesothelioma cells, even though no evidence for a direct CSL/RBP-J $\kappa$-dependent effect was reported [44]. In pancreatic cancer cells, Notch signaling seems to regulate the phosphorylation rather than the transcription of PTEN [45]. Moreover, it has been recently reported that in normal and cancerous thymocytes loss of PTEN expression is partly due to HES1-dependent repression, suggesting a Notch-mediated indirect regulation in this cellular context $[46,47]$. However, since Notch1 and JAG1 are up-regulated in SS [33], the possibility that the down-regulation of PTEN observed in these tumor may be, at least in part, related to Notch1 signaling de-regulation deserves further investigation.

\section{Notch signaling in Ewing Sarcoma}

The ES family tumors include sarcomas affecting bone and soft tissues in children and adolescents. They presumably 
Table 1 Notch signaling in STS.

\begin{tabular}{|c|c|c|c|c|}
\hline Tumor & Results & Notch componentinvolved & $\begin{array}{l}\text { Role of Notch } \\
\text { signaling }\end{array}$ & Reference \\
\hline \multirow[t]{3}{*}{ Synovial sarcoma } & & Notch1, JAG1 and TLEs over-expression & Pro-tumor & [33] \\
\hline & & TLE1 over-expression & Pro-tumor & {$[36-39]$} \\
\hline & $\begin{array}{c}\text { Prevents EGR1 expression } \\
\text { Reduces apoptosis } \\
\text { Promotes cell growth } \\
\text { Favors epigenetic gene repression }\end{array}$ & TLE1 over-expression & Pro-tumor & [41] \\
\hline \multirow[t]{3}{*}{ Ewing's sarcoma } & $\begin{array}{c}\text { Prevents differentiation } \\
\text { Increases cell proliferation } \\
\text { Decreases apoptosis } \\
\text { Supports tumor growth in vivo }\end{array}$ & $\begin{array}{l}\text { Manic Fringe expression } \\
\text { Notch1 ICD over-expression }\end{array}$ & $\begin{array}{l}\text { Onco- } \\
\text { suppressor } \\
\text { Regulates } \\
\text { differentiation }\end{array}$ & [51] \\
\hline & $\begin{array}{c}\text { In p53 wild-type tumor cells: Induces p53 } \\
\text { Blocks cell proliferation } \\
\text { Inhibits soft agar colony formation }\end{array}$ & $\begin{array}{l}\text { JAG1 and HEY1 down-regulated by EWS- } \\
\text { FLI1 and Notch3 }\end{array}$ & $\begin{array}{l}\text { Onco- } \\
\text { suppressor }\end{array}$ & [52] \\
\hline & Prevents cell proliferation & Notch1 and Notch3 & $\begin{array}{l}\text { Onco- } \\
\text { suppressor }\end{array}$ & [54] \\
\hline \multirow[t]{5}{*}{ Rhabdomyosarcoma } & $\begin{array}{l}\text { Supports cell proliferation } \\
\text { Inhibits apoptosis } \\
\text { Prevents differentiation }\end{array}$ & $\begin{array}{l}\text { HES1 over-expression in RMS primary } \\
\text { samples and in cell lines }\end{array}$ & Pro-tumor & [68] \\
\hline & $\begin{array}{l}\text { Increases cell migration } \\
\text { Increases cell invasion }\end{array}$ & $\begin{array}{c}\text { Notch2 and HEY1 over-expressed in } \\
\text { patients with alveolar RMS and } \\
\text { embryonal RMS }\end{array}$ & Pro-tumor & [69] \\
\hline & $\begin{array}{l}\text { Increases cell proliferation } \\
\text { Supports tumor growth in vivo }\end{array}$ & $\begin{array}{l}\text { Notch1 ICD and HEY1 over-expressed in } \\
\text { primary embryonal RMS and cell lines }\end{array}$ & Pro-tumor & [70] \\
\hline & $\begin{array}{l}\text { Prevents differentiation } \\
\text { Supports cell proliferation } \\
\text { Supports tumor growth in vivo }\end{array}$ & $\begin{array}{c}\text { Notch3 ICD and HES1 over-expressed in } \\
\text { alveolar RMS and embryonal RMS cell } \\
\text { lines }\end{array}$ & Pro-tumor & [71] \\
\hline & $\begin{array}{l}\text { Supports cell proliferation and anchorage- } \\
\text { independence in vitro and tumor growth in vivo }\end{array}$ & $\begin{array}{l}\text { RBP- } J \kappa \text { over-expressed in embryonal } \\
\text { RMS primary tissues and cell lines }\end{array}$ & Pro-tumor & [76] \\
\hline
\end{tabular}

derive from a MSC precursor and some of them express neuroectodermal markers such as neuron-specific enolase [48]. More than $80 \%$ of ES express EWS-FLI1 chimeric onco-proteins generated by the fusion of the ES breakpoint region ( $E W S$ ) gene on chromosome 22q12 with genes of the E transformed specific transcription factor (ETS) family, mostly the Friend leukemia virus integration 1 (FLI1) gene on chromosome 11q24. These proteins act as transcription factors with different transcriptional abilities and gene targets compared to wild-type single products. EWS-FLI1 proteins, exogenously expressed in murine fibroblasts or present in ES cell lines, stimulate the transcription of MFNG, the enzyme that regulates the glycosylation of Notch receptors and, therefore, their affinity for ligands $[49,50]$. Based on these results, the involvement of Notch signaling in ES pathogenesis was recently investigated (Table 1) [51]. Ten EWS-FLI1-expressing primary ES samples and two cell lines evaluated in this work showed the expression of at least one of the Notch receptors and several ligands, while all expressed the Notch target gene HES1 and the glycosylation enzyme MFNG. HES1 expression in ES cell lines was inhibited via expression of a dominant-negative Notch1 or the use of a GSI, while it was increased after expression of active Notch1 ICD. However, the two ES cell lines used in this work behave in a different manner after Notch inhibition, only one of them showing reduction of cell proliferation and cell apoptotic rate. Inhibition of Notch signaling did not result in reduced tumor growth in vivo but rather in neuroectodermal differentiation of tumor xenografts. Therefore, the authors suggested that Notch signaling activation is responsible for the loss of differentiation in ES but it does not play a direct pro-tumorigenic role [51].

More recently, Ban et al., investigating the role of EWS-FLI1 in p53 induction and cell cycle arrest in ES cells, discovered a link between the fusion onco-protein and Notch signaling [52]. Indeed, upon EWS-FLI1 silencing, wild-type p53 ES cells showed p53 activation and triggering of the molecular cascade involving the cyclindependent kinase (CDK) inhibitor p21 ${ }^{\mathrm{Cip} 1}$ leading to cell growth arrest followed by apoptosis. The gene expression profiling of EWS-FLI1-depleted cells, analyzed in order to investigate the molecular pathways involved in p53 induction, showed the induction of both the Notch ligand JAG1 and the Notch target gene HEY1. HEY1 silencing counteracted the induction of $\mathrm{p} 53$ in response to EWS-FLI1 depletion, while forced expression of $H E Y 1$ was sufficient to induce p53 nuclear accumulation also in EWS-FLI1-expressing cells resulting in cell cycle arrest. This observation strongly suggests that EWS-FLI1 down-regulation triggers a 
HEY1-dependent p53 induction, blocking cell proliferation. Apoptotic pathways activation appeared to be mediated by other mechanisms. Subsequent studies demonstrated that HEY1 transcription is due to activation of the Notch3 receptor, the most highly expressed Notch receptor in both ES primary tumors and cell lines, by JAG1 (Jagged1). Jagged1 over-expression was observed after EWS-FLI1 knockdown. Notch3 signaling was inhibited through either JAG1 silencing, GSI or over-expression of Notch negative regulator NUMB. Interestingly, even the role of NUMB in the degradation of Notch3 seems to be cell/context-dependent underscoring the complexity of Notch signaling in normal and pathological contexts [53]. All these approaches resulted in reduction of both $\mathrm{p} 53$ and $\mathrm{p} 21^{\mathrm{Cip} 1}$ up-regulation. Conversely, forced expression of either JAG1 or DLL1 was capable of inducing p53 expression and nuclear accumulation, and HEY1 silencing reversed this effect indicating that the induction of p53 is HEY1-dependent in this context. Finally, Ban and colleagues identify a potential EWS-FLI1 binding site on the JAG1 promoter that could repress the expression of JAG1, as suggested by luciferase experiments. Therefore, in ESs that retain wild-type p53, Notch signaling seems to act as a tumor suppressor rather than as ancogene, as reported for the majority of adult epithelial tumors. This would explain the failure of tumor growth inhibition observed in the previous report [51]. Importantly, differently from ES cells depleted of EWS-FLI1, HEY1 was not modulated after Notch inhibition in ES cells expressing EWSFLI1, suggesting that Notch signaling is inactive in the presence of the fusion onco-protein. In a subsequent manuscript, the same group studied the activation status of Notch signaling in ES primary tumors by immunohistochemistry in order to identify the cause of the high transcriptional expression of Notch target gene HES1 found in ES tumors [54]. They noticed that, although the mRNA of at least one Notch receptor was expressed and that of HES1 was up-regulated, Notch signaling appeared to be inactive in a set of 22 of 24 ES samples. Indeed, the Notch cleaved products, that is, Notch ICDs, and HES1 protein, were not present in the nucleus, as demonstrated by the absence of nuclear staining. Consistent with this observation, the high mRNA expression of HES1 found in all the samples was not correlated with Notch receptor mRNA expression. HES1 expression was independent of both EWS-FLI1 expression and Notch signaling inhibition achieved with different means, nor was it induced by expression of Notch1 or Notch3 ICD, suggesting that it is regulated by other pathways in ES cells. Moreover, while Notch1 ICD and Notch3 ICD over-expression was sufficient to prevent the proliferation of ES cells, blockade of HES1 did not have any effect.

A recently discovered link between ES pathogenesis and epigenetic pathways could have implications for Notch signaling inactivation in this tumor [55]. Lysine-specific demethylase 1 (LSD1 or KMD1A) was shown to be overexpressed in 59 ES and 7 rhabdomyosarcoma (RMS) primary samples compared to normal MSCs, as already reported for primary samples of RMS and SS [56]. Pharmacologic inhibition of LSD1 induced p53 expression and prevented proliferation in several ES cell lines, re-establishing the H3K4 methylation, as reported for SS cell lines [55]. In addition to having a primary role in epithelial-mesenchymal transition (EMT), LSD1 stimulates cell proliferation and survival by binding histone deacetylase complexes and specifically demethylating both Lysine 4 and Lysine 9 on histone H3 (H3K4 and H3K9). LSD1 works by forming co-repressor complexes with HDACs, such as sirtuin 1 (SIRT1), and inhibits the transcription of Notch target genes such as HES1 in human normal cells, and HES1 and HEY1 in murine normal cells [57]. This finding has been previously reported in murine embryos, where LSD1 represses the expression of HEY1 during brain development [58] and Enhancer of Split (a corresponding HEY1 gene) during Drosophila development [59]. The working model involves binding of LSD1/SIRT1 complexes to CSL/RBP-J $\kappa$ during repression of HES1 and release of LSD1/SIRT1 complexes from CSL by Notch ICD. Therefore, the inhibition of LSD1 in ES could remove the brake for the transcription of Notch target gene HEY1 even in the presence of EWS-FLI1, as suggested by the expression of p53, thus mimicking and/or augmenting the effects of EWS-FLI1 silencing.

\section{Notch signaling in Rhabdomyosarcoma}

RMS is the most common pediatric STS accounting almost for $7 \%$ to $8 \%$ of all childhood malignancies [60]. It includes two major histopathological pediatric subtypes, embryonal and alveolar, presenting different genetic abnormalities. Embryonal RMS occurs in about $70 \%$ of cases and has a good prognosis if it is non-metastatic at diagnosis. In contrast, alveolar RMS is often associated with a worse prognosis. In about $75 \%$ of cases, the alveolar form is characterized by specific chromosomal translocations such as $\mathrm{t}(2 ; 13)$ or $\mathrm{t}(1 ; 13)$ that produce paired box 3-forkhead box O1 (PAX3-FOXO1) or PAX7-FOXO1 fusion onco-proteins. Their expression is correlated with poor prognosis, with an approximately $25 \%$ five-year overall survival rate for both PAX-FOXO1 positive alveolar and metastatic patients [61-64]. RMS is thought to derive from skeletal muscle progenitors that, although they retain expression of skeletal muscle markers such as MyoD and Myogenin, have lost the ability to differentiate and proliferate indefinitely. Therefore, strategies aimed at re-establishing differentiation programs are thought to have anti-cancer potential. Notch signaling is one of the major regulators of embryonic 
and post-natal skeletal muscle differentiation [65-67] and, therefore, could be implicated in RMS development. Consistent with this hypothesis, Sang et al. demonstrated that the Notch target gene HES1 was over-expressed in RMS primary tumors and cell lines compared to normal muscle, and its inhibition through a dominant-negative HES1 form promoted skeletal muscle-like differentiation of RMS cells (Table 1) [68]. Inhibition of Notch signaling with GSIs phenocopied this pro-myogenic effect and lowered HES1 expression, suggesting that HES1 de-regulation in RMS is Notchdependent. In view of this important result, three reports published by our group and others in the last two years have confirmed a role of Notch signaling in RMS pathogenesis, unveiling several Notch-regulated mechanisms [69-71]. In 37 primary RMS samples, whether alveolar or embryonal, transcript levels of Notch2 and HEY1 were found significantly up-regulated, while Notch 3 was slightly increased as compared to both adult and fetal muscle [69]. No significant over-expression was observed for either Notch1 or Notch4 mRNAs whereas a modest up-regulation of HES1 was found only in embryonal RMS samples. However, immunohistochemical nuclear staining for HES1 showed that it was over-expressed in the majority of tumor samples. HES1 levels correlated with tumor migration and invasive features of RMS cell lines in vitro, being modest in embryonal subtype cells with low invasive activity, high in highly invasive PAX7-FOXO1 alveolar cells and very high in PAX3-FOXO1 alveolar cells with the highest invasiveness. Treatment with GSIs or with a dominant-negative form of MAML1, a canonical Notch nuclear co-activator, prevented cell invasion with no effects on cell proliferation. More recently, HEY1 mRNA levels were shown to be significantly higher in the embryonal compared with the alveolar subtype in four RMS cell lines and a previously published cohort of primary RMS [62,70]. Consistent with a role of Notch1-target gene $H E Y 1$ in muscle progenitors $[72,73]$, Notch1 protein levels were shown to be significantly up-regulated in embryonal RMS. A role of Notch1 and HEY1 over-expression in embryonal RMS is supported by the inhibition of cell proliferation in tumor cell lines depleted of either Notch1 or HEY1. Moreover, sustained silencing of HEY1 increased the expression of the myogenic differentiation factor Myogenin in embryonal RMS cells cultured in a medium that promotes cell proliferation (growth medium; GM), and even more in medium that promotes myotube fusion (differentiation medium; DM). However, no overt phenotypic signs of muscle-like differentiation and myotube fusion were detected after HEY1 knockdown, suggesting a role for the Notch1-HEY1 axis in the regulation of proliferative rather than differentiative pathways in embryonal RMS cells. Similar in vitro effects were observed after pharmacologic treatment with a GSI and were reversed by forced expression of an exogenous Notch1 ICD. Notch1 knockdown in RMS cell lines reduces or abolishes tumorigenicity in xenografts. This effect is confirmed with a GSI that decreased Notch1 ICD in tumor samples. Our investigations on Notch pathway in RMS biology, published some months later, expand the scenario, implicating Notch 3 as a major cause of the inability of RMS cells to differentiate, irrespective of their subtype. In a set of three embryonal and two alveolar cell lines over-expressing transcripts of Notch1, Notch3 and HES1 compared to normal human skeletal myoblasts, the cleaved forms of these receptors, Notch1 ICD and Notch3 ICD were detected in the nucleus. Interestingly, tumor cells had similar Notch2 mRNA and protein levels to normal myoblasts, but the latter showed higher Notch2 ICD levels. Notch2 ICD was detected in nuclear extracts of all the cell lines studied, suggesting that this signal may be active in these RMS cell lines. Consistent with data from Sang et al., HES1 was upregulated at the mRNA and protein levels in all the cell lines examined. Notch3 silencing in both one embryonal and one alveolar RMS cell line resulted in the formation of myotube-like structures expressing markers of terminal skeletal muscle differentiation such as myosin heavy chain and troponin. This finding is consistent with a role of Notch3 activation/expression in the myoblast-to-myofibroblast trans-differentiation induced by TGF $\beta$ treatment [74]. In agreement with these observations, Notch3 knockdown noticeably led to a decrease in HES1 expression associated with the activation of myogenic pathways necessary for terminal differentiation such as $\mathrm{p} 38$ and AKT. Moreover, JAG1 depletion strongly reduced both Notch 3 ICD and HES1 levels, suggesting that Notch3 activation results, at least in part, from binding to Jagged-family ligands rather than from activating mutations. High throughput sequencing analysis on 75 ES and 89 RMS samples did not demonstrate any Notch1 mutations [75]. Notch1 silencing had a lesser effect on the differentiation of the embryonal cell line, slightly increasing the expression of myogenin, and no effect in the alveolar cell line. These results are in keeping with data from Linardic and colleagues, establishing that Notch1 signaling controls neither cell differentiation nor HES1 expression in embryonal RMS [70]. Strikingly, Notch2 knockdown reduced myogenin expression and promoted HES1 expression, indicating that Notch2 could play an opposite role in RMS cells compared to Notch3, as already suggested for skeletal muscle tissue commitment [74]. The triggering of differentiation upon Notch3 knockdown was associated with cell cycle arrest, p2 $1^{\text {Cip } 1}$ induction and a decrease in the levels of kinases regulating cell proliferation such as ERK-1 and -2. All these effects were mimicked in wild-type cells or reinforced in Notch3-depleted cells by HES1 silencing, whereas HES1 over-expression partly reversed the effects of Notch3 
knockdown. Consistent with the observations of Sang et al. [68], these results strongly indicate that the in vitro antidifferentiative and pro-tumorigenic role of Notch3 in RMS is, at least in part, due to the induction of HES1 expression. Finally, Notch3 depletion, even only in a fraction of cells, inhibited the growth of alveolar RMS tumors xenografted in immune-compromised mice. Very recently, Nagao and colleagues showed that the CSL/RBP-Jk is necessary for the growth of embryonal RMS cells in vitro and in vivo and that its function is Notch activation-dependent [76]. All these results support a major role for the Notch signaling pathway in the maintenance of the malignant phenotype in RMS.

\section{Notch signaling inhibition in cancer treatment: from preclinical studies to clinical evidence}

Notch inhibition may represent a powerful approach to restrain tumorigenesis of STSs in which Notch signaling is over-active, such as RMS [69-71], and potentially, SS. Different classes of inhibitors have been tested in preclinical studies aimed at evaluating the feasibility of Notch inhibition as an anti-cancer strategy. These include GSIs [77], specific anti-Notch antibodies [78,79], Notch ligand decoys [80], and inhibitors of the Notch transcription complex [81]. Due to the role of Notch signaling in preventing differentiation and maintaining stem cell populations, these inhibitors are expected to induce differentiation and prevent proliferation and metastasis. Among preclinical Notch inhibitors, GSIs and some ligand mAbs have been tested in clinical trials for the treatment of human cancers.

GSIs, originally developed to block the cleavage of $\beta$ amyloid precursor protein in Alzheimer's disease, inhibit the final cleavage that produces the ICD of Notch receptors. However, they also inhibit the cleavage of many other $\gamma$-secretase-targeted proteins [82]. Thus, GSIs are not technically specific Notch inhibitors but their in vivo toxicity appears to result exclusively from Notch inhibition. Indeed, secretory diarrhea secondary to goblet cell metaplasia of the small intestine is due to inhibition of Notch1 and Notch2 cleavage in intestinal epithelial stem cells, and is mimicked by double knockout of Notch1 and Notch 2 in these cells $[83,84]$. GSIs, at least theoretically, are not specific for individual Notch receptors. However, currently available investigational GSIs belong to several different chemical series, and the specificity of different classes of GSIs has not been studied in detail. Most biochemical studies on GSIs have traditionally focused on Notch1. The widespread assumption that all GSIs are pharmacologically equivalent and inhibit all Notch paralogs may be unwarranted. Harrison et al. [85] reported that Notch4 is resistant to two commercially available GSIs. Whether clinical GSIs also inhibit different Notch paralogs with different potencies remains to be determined. Initial results from clinical studies on patients with Alzheimer's disease reported targetmediated side effects of GSIs, such as secretory diarrhea, nausea and fatigue [86]. Nevertheless, a re-evaluation of case reports showed some therapeutic benefits and relatively low toxicity. For oncologic indications, intermittent administration of GSIs has been shown to decrease toxicity significantly. MK-0752 is an oral GSI. Its safety and efficacy as an anticancer drug have been tested in clinical trials with both adult and pediatric patients (Table 2) $[87,88]$. In a phase I study in children with recurrent central nervous system (CNS) malignancies, MK-0752 was well tolerated at the dose and schedule recommended for phase II study progression [87]. Two of nine patients experienced prolonged disease stabilization. Importantly, only in the two responders did MK-0752 decrease the levels of Notch1 ICD in post-treatment peripheral blood mononuclear cells [87]. This finding underscores a fundamental issue in the development-targeted agents, including Notch inhibitors. Robust biological markers demonstrating target inhibition should be included in all clinical trials of such agents for the results to be interpretable. Ideally, target inhibition in tumor tissue should be documented. In a phase I clinical trial conducted in adult patients with solid tumors, MK-0752 demonstrated good tolerability and evidence of Notch pathway inhibition using a once-per-week dosing schedule. Preliminary evidence of efficacy was observed mainly in patients with gliomas. Conversely, there was little evidence of efficacy of MK-0752 as a single agent in patients with extra-cranial cancers, this indicating the need for rational, mechanism-based combinations [88]. The importance of combination approaches is illustrated by a recently closed pilot pre-surgical clinical trial of MK-0752 in estrogen receptor $(E R+)$ breast cancer ([89] and manuscript in preparation). In this study, which was based on extensive preclinical data documenting cross-talk of Notch with ER [90,91], MK0752 GSI was administered after two weeks of endocrine therapy with tamoxifen or letrozole, concomitantly with continued endocrine therapy. Under these conditions, no diarrhea was observed and Ki67 reduction compared to endocrine therapy alone was seen in 17 of 20 patients. Induction of apoptosis (as detected by upregulation of the pro-apoptotic mediator NOXA), was seen in 15 of 20 patients. Notch pathway inhibition by GSIs in tumor tissue was documented using multiple QRT-PCR assays on tumor biopsies taken at diagnosis, after endocrine therapy alone and after the addition of GSI. A chemically different GSI, RO4929097, has shown antitumor activity in animal models with a concomitant differentiated histologic profile, typical of Notch inhibition. Because of its promising preclinical activity and tolerability RO4929097 has been studied in phase I clinical trials [92]. Tolcher et al. have reported that in a phase I study RO4929097 was well tolerated in adult patients with 
Table 2 Completed clinical trials with $\gamma$-secretase inhibitors in pediatric/young adult oncologic patients (clinicaltrials. gov).

\begin{tabular}{|c|c|c|c|c|}
\hline Compound & $\begin{array}{c}\text { ClinicalTrials Gov } \\
\text { Identifier }\end{array}$ & $\begin{array}{l}\text { Clinical } \\
\text { studies }\end{array}$ & Cancer type & Patients'age \\
\hline MK0752 & NCT00106145 & Phase I study & Breast and advanced solid tumors & 18 Years and older \\
\hline MK0752 & NCT00100152 & Phase I study & T-ALL & $\begin{array}{l}12 \text { Months and } \\
\text { older }^{\mathrm{a}}\end{array}$ \\
\hline RO4929097 & NCT01192763 & Phase I study & Pancreatic cancer & 18 Years and older \\
\hline RO4929097 & NCT01208441 & Phase I study & Breast cancer & 18 Years and older \\
\hline RO4929097 & NCT01269411 & Phase I study & Brain and Central Nervous System Tumors & 18 Years and older \\
\hline RO4929097 & NCT01216787 & Phase II study & Melanoma (Skin) & 18 Years and older \\
\hline RO4929097 & NCT01217411 & Phase I study & Breast Cancer & 18 Years and older \\
\hline RO4929097 & NCT01151449 & Phase II study & Breast Cancer & 18 Years and older \\
\hline $\begin{array}{l}\text { RO4929097 with or without } \\
\text { Bevacizumab }\end{array}$ & NCT01270438 & Phase II study & Metastatic Colorectal Cancer & 18 Years and older \\
\hline RO4929097 & NCT01236586 & $\begin{array}{l}\text { Phase } 1 / \| \\
\text { study }\end{array}$ & $\begin{array}{c}\text { Brain and Central Nervous System Tumors, } \\
\text { T-ALL }\end{array}$ & 1 Year to 21 Years $^{a}$ \\
\hline RO4929097 & NCT01088763 & $\begin{array}{l}\text { Phase } \mid / / I \\
\text { study }\end{array}$ & Leukemia & 1 Year to 21 Years $^{a}$ \\
\hline
\end{tabular}

${ }^{a}$ Enrollment of children. T-ALL, T-cell acute lymphoblastic leukemia/lymphoma.

refractory metastatic or advanced solid tumors and some evidence of antitumor activity was observed [93]. However, Strosberg et al. in a phase II study showed that patients with refractory metastatic colorectal cancer treated with RO4929097 did not have radiographic responses, suggesting that $\mathrm{RO} 4929097$ at the study dose and schedule has minimal single agent activity in this malignancy [94]. It should be noted that RO4929097 has auto-inducing properties (it induces its own liver metabolism) and this may represent a pharmacokinetic liability. Nevertheless, to expect single agent activity in early clinical trials with developmental pathway inhibitors may be unrealistic. Unlike cytotoxic agents, drugs targeting developmental pathways are not relatively non-specific poisons and do not often kill target cells at pharmacologically attainable doses. What many of these agents do is to reset cell fate programs increasing sensitivity to differentiation stimuli, growth arrest stimuli or cytotoxic stimuli. Additionally, it is likely that the main target of these agents is not bulk tumor cells but tumor-initiating cells. Therefore, the main therapeutic effect of these agents may lie in prevention of recurrence rather than rapid tumor shrinkage. This was demonstrated in a recent study in Her2/Neu positive xenografts, in which two chemically distinct GSIs (MRK003 and LY411,575) were studied alone and in combination with Herceptin (trastuzumab )[95]. In this study, neither GSI had any effect on tumor volume as single agents or in combination with Herceptin. Herceptin alone had dramatic effects, leading to apparently complete tumor regression. However, when tumor recurrence was studied, MRK003 in combination with Herceptin completely abolished tumor regression, while LY411575 nearly abolished it. Animals treated with Herceptin alone showed approximately $50 \%$ tumor recurrence after complete regression, which is similar to patients treated with Herceptin-containing regimens. Thus, it is likely that the effects of GSIs and potentially other Notch inhibitors may be clinically very significant in terms of longterm survival, but will have to be evaluated with appropriate surrogate endpoints and in mechanism-based, rationally designed combinations. In fact, trials designed to combine GSIs with other agents, including tyrosine kinase inhibitors, mammalian target of rapamycin inhibitors, aromatase inhibitors, and conventional chemotherapeutic compounds are currently recruiting patients [96]. Consistent with this view, in a recently closed US National Cancer Institute sponsored phase I/ II study at the Memorial Sloan-Kettering Cancer Center, (New York, NY, USA) (NCT01154452), RO4929097 has been administered in combination with a hedgehog inhibitor, GDC-0449, for the treatment of adult patients with advanced and/or metastatic sarcomas, including SS. The objectives of this study were to determine the maximum-tolerated dose of RO4929097 combined with GDC-0449 (Phase Ib) and to assess the progression-free survival of patients treated with RO4929097 alone or with the hedgehog antagonist (Phase II). Studies like this may hold the key to future development of Notchmodulating agents in pediatric sarcomas, and for that matter in other tumors.

\section{Conclusions}

Taken together, the results we have summarized suggest that Notch inhibition may be a promising approach in the treatment of several types of human pediatric cancers, but more work needs to be done to assure a successful clinical translation. The role of individual Notch paralogs in 
specific tumor subtypes will dictate whether a relatively non-specific approach such as a GSI or more specific agents, such as Notch receptor or ligand monoclonal antibodies, should be preferred [44]. Not surprisingly, several academic and pharmaceutical groups are developing specific Notch receptor and Notch ligand antibodies [77]. In tumors in which Notch signaling plays a tumor-suppressive role, such as ES $[51,52,54]$, agents that can selectively activate Notch receptors or induce downstream molecules such as HEY1 may be promising therapeutic approaches.

Overall, preclinical studies suggest that an anti-cancer approach aimed at promoting differentiation in STS is feasible and deserves further investigation. Given the prominent role of Notch signaling in numerous aspects of tumor development and maintenance, the Notch pathway is a potentially attractive therapeutic target for several types of STS.

\begin{abstract}
Abbreviations
ATF2: activating transcription factor 2; CDK: cyclin-dependent kinase; CNS: central nervous system; CSL: DNA binding protein transcriptional complex; DLL1: Delta-like 1; DLL3: Delta-like 3; DLL4: Delta-like 4; EGR1: Early Growth Response-1; ES: Ewing sarcoma; ETS: E transformed specific transcription factor; EWS: Ewing sarcoma breakpoint region; EZH2: Enhancer of Zeste Homolog 2; FLI1: Friend leukemia virus integration 1; FOXO1: forkhead box O1; GSI: $\gamma$-secretase inhibitor; HDAC: histone deacethylase; ICD: Notch intracellular domain; LFNG: Lunatic Fringe enzyme; LSD1: lysine-specific demethylase 1; MFNG: Manic Fringe enzyme; MSC: mesenchymal progenitor/ stem cell; PAX3: paired box 3; PAX7: paired box 7; PEST: C-terminal proline: glutamic acid: serine and threonine degradation domain; PRC2: Polycomb Repressor Complex 2; PTEN: Phosphatase and Tensin homolog deleted in chromosome 10; QRT-PCR: quantitative reverse transcriptase-polymerase chain reaction; RBP-Jk: Recombination signal Binding Protein for immunoglobulin Kappa J region; RFNG: Radical Fringe enzyme; RMS: rhabdomyosarcoma; SIRT1: sirtuin 1; SS: synovial sarcoma; SS18: synovial sarcoma translocation: chromosome 18; SSX1: Synovial Sarcoma: $\times$ breakpoint 1; SSX2: Synovial Sarcoma: $\times$ breakpoint 2; SSX4: Synovial Sarcoma: $\times$ breakpoint 4; STS: soft tissue sarcoma; T-ALL: acute T-cell leukemia; TGF $\beta$ : tumor growth factor $\beta$; TLE: Transducin-like Enhancer of split genes.
\end{abstract}

\section{Acknowledgements}

The present work was supported by grants from Ministero della Sanità Italia (Ricerca Corrente), Associazione Italiana per la Ricerca sul Cancro (AIRC Project 10338) to RR and by grants from Ministero della Salute, Italia (Ricerca Corrente) and AIRC (Special Project $5 \times$ mille) to FL.

\section{Author details}

'Department of Oncohematology, Ospedale Pediatrico Bambino Gesù, IRCCS, Piazza Sant'Onofrio 4, Roma, 00165, Italy. ${ }^{2}$ Cancer Institute, University of Mississippi Medical Center, 2500 N. State Street, Guyton 2 Building, Suite G751-05, Jackson, Mississippi, 39216, USA. ${ }^{3}$ Dipartimento di Scienze Pediatriche, Policlinico San Matteo, IRCCS, Università di Pavia, Viale Camillo Golgi 19, Pavia, 27100, Italy.

\section{Authors' contributions}

RR conceived the outline of the manuscript, selected the literature, and wrote the manuscript. RC contributed to the selection of literature on clinical trials and to the initial version of the manuscript. FL and LM contributed to the discussion on clinical implications and critically reviewed the manuscript. All authors read and approved the final version of the manuscript.

\section{Authors' information}

RR is a PhD and the Group leader of the Laboratory of Angiogenesis with experience in mechanisms that regulate gene expression and cell growth in pediatric cancers. $\mathrm{RC}$ is a PhD working on transcriptional regulation in cancer in the Laboratory of Angiogenesis directed by RR. LM is an MD and the Director of the Cancer Centre and Professor of Medicine and Pharmacology at the Jackson University which is committed to preclinical and clinical research against breast cancer. FL is an MD and Full Professor of Pediatrics and the Head of the Oncohematology Department with a longstanding experience in preclinical research and clinical management of pediatric tumor patients.

\section{Competing interests}

The authors declare that they have no competing interests.

Received: 1 August 2012 Accepted: 16 November 2012

Published: 16 November 2012

\section{References}

1. Boyer-Di Ponio J, Wright-Crosnier C, Groyer-Picard MT, Driancourt C, Beau I, Hadchouel M, Meunier-Rotival M: Biological function of mutant forms of JAGGED1 proteins in Alagille syndrome: inhibitory effect on Notch signaling. Hum Mol Genet 2007, 16:2683-2692.

2. Federico A, Bianchi S, Dotti MT: The spectrum of mutations for CADASIL diagnosis. Neurol Sci 2005, 26:117-124.

3. Sparrow DB, Chapman G, Wouters MA, Whittock NV, Ellard S, Fatkin D, Turnpenny PD, Kusumi K, Sillence D, Dunwoodie SL: Mutation of the LUNATIC FRINGE gene in humans causes spondylocostal dysostosis with a severe vertebral phenotype. Am J Hum Genet 2006, 78:28-37.

4. Koch U, Radtke F: Notch in T-ALL: new players in a complex disease. Trends Immunol 2011, 32:434-442.

5. Grill J, Bergthold G, Ferreira C: Pediatric ependymomas: will molecular biology change patient management? Curr Opin Oncol 2011, 23(6):638-642.

6. Lobry C, Oh P, Aifantis I: Oncogenic and tumor suppressor functions of Notch in cancer: it's NOTCH what you think. J Exp Med 2011, 208:1931-1935.

7. Pannuti A, Foreman K, Rizzo P, Osipo C, Golde T, Osborne B, Miele L: Targeting Notch to target cancer stem cells. Clin Cancer Res 2010, 16:3141-3152.

8. Wang Z, Ahmad A, Li Y, Azmi AS, Miele L, Sarkar FH: Targeting notch to eradicate pancreatic cancer stem cells for cancer therapy. Anticancer Res 2011, 31:1105-1113.

9. Sethi $N$, Kang $Y$ : Notch signalling in cancer progression and bone metastasis. Br J Cancer 2011, 105:1805-1810.

10. Ellisen LW, Bird J, West DC, Soreng AL, Reynolds TC, Smith SD, Sklar J: TAN1 , the human homolog of the Drosophila notch gene, is broken by chromosomal translocations in T lymphoblastic neoplasms. Cell 1991, 66:649-661.

11. Weng AP, Ferrando AA, Lee W, Morris JP, Silverman LB, Sanchez-lrizarry $C$, Blacklow SC, Look AT, Aster JC: Activating mutations of NOTCH1 in human T cell acute lymphoblastic leukemia. Science 2004, 306:269-271

12. Jemal A, Siegel R, Xu J, Ward E: Cancer statistics, 2010. CA Cancer J Clin 2010, 60:277-300.

13. Ciarapica R, Miele L, Giordano A, Locatelli F, Rota R: Enhancer of zeste homolog $2(E Z H 2)$ in pediatric soft tissue sarcomas: first implications. BMC Med 2011, 9:63.

14. Taylor BS, Barretina J, Maki RG, Antonescu CR, Singer S, Ladanyi M: Advances in sarcoma genomics and new therapeutic targets. Nat Rev Cancer 2011, 11:541-557.

15. Tirode F, Laud-Duval K, Prieur A, Delorme B, Charbord P, Delattre O: Mesenchymal stem cell features of Ewing tumors. Cancer Cell 2007, 11:421-429.

16. Torchia EC, Jaishankar S, Baker SJ: Ewing tumor fusion proteins block the differentiation of pluripotent marrow stromal cells. Cancer Res 2003, 63:3464-3468.

17. Walter D, Satheesha S, Albrecht P, Bornhauser BC, D'Alessandro V, Oesch SM, Rehrauer H, Leuschner I, Koscielniak E, Gengler C, Moch H, Bernasconi M, Niggli FK, Schafer BW: CD133 positive embryonal rhabdomyosarcoma stem-like cell population is enriched in rhabdospheres. PLoS One 2011, 6:e19506.

18. De Vito C, Riggi N, Cornaz S, Suva ML, Baumer K, Provero P, Stamenkovic I: A TARBP2-dependent miRNA expression profile underlies cancer stem cell properties and provides candidate therapeutic reagents in Ewing sarcoma. Cancer Cell 2012, 21:807-821. 
19. Andersson ER, Sandberg R, Lendahl U: Notch signaling: simplicity in design, versatility in function. Development 2011, 138:3593-3612.

20. Kopan R, llagan MX: The canonical Notch signaling pathway: unfolding the activation mechanism. Cell 2009, 137:216-233.

21. Iso T, Kedes L, Hamamori Y: HES and HERP families: multiple effectors of the Notch signaling pathway. J Cell Physiol 2003, 194:237-255.

22. Rustighi A, Tiberi L, Soldano A, Napoli M, Nuciforo P, Rosato A, Kaplan F, Capobianco A, Pece S, Di Fiore PP, Del Sal G: The prolyl-isomerase Pin1 is a Notch1 target that enhances Notch1 activation in cancer. Nat Cell Biol 2009, 11:133-142.

23. Ishitani T, Hirao T, Suzuki M, Isoda M, Ishitani S, Harigaya K, Kitagawa M, Matsumoto K, Itoh M: Nemo-like kinase suppresses Notch signalling by interfering with formation of the Notch active transcriptional complex. Nat Cell Biol 2010, 12:278-285.

24. Sanalkumar R, Dhanesh SB, James J: Non-canonical activation of Notch signaling/target genes in vertebrates. Cell Mol Life Sci 2010, 67:2957-2968.

25. Perumalsamy LR, Marcel N, Kulkarni S, Radtke F, Sarin A: Distinct spatial and molecular features of notch pathway assembly in regulatory $\mathrm{T}$ cells. Sci Signal 2012, 5:ra53.

26. Gu JW, Rizzo P, Pannuti A, Golde T, Osborne B, Miele L: Notch signals in the endothelium and cancer "stem-like" cells: opportunities for cancer therapy. Vasc Cell 2012, 4:7.

27. Dotto GP: Notch tumor suppressor function. Oncogene 2008, 27:5115-5123.

28. Dumortier A, Durham AD, Di Piazza M, Vauclair S, Koch U, Ferrand G, Ferrero I, Demehri S, Song LL, Farr AG, Leonard WJ, Kopan R, Miele L, Hohl D, Finke D, Radtke F: Atopic dermatitis-like disease and associated lethal myeloproliferative disorder arise from loss of Notch signaling in the murine skin. PLoS One 2010, 5:e9258.

29. Haldar M, Randall RL, Capecchi MR: Synovial sarcoma: from genetics to genetic-based animal modeling. Clin Orthop Relat Res 2008, 466:2156-2167.

30. Naka N, Takenaka S, Araki N, Miwa T, Hashimoto N, Yoshioka K, Joyama S, Hamada K, Tsukamoto Y, Tomita Y, Ueda T, Yoshikawa H, Itoh K: Synovial sarcoma is a stem cell malignancy. Stem Cells 2010, 28(7):1119-1131.

31. Cironi L, Provero P, Riggi N, Janiszewska M, Suva D, Suva ML, Kindler V, Stamenkovic I: Epigenetic features of human mesenchymal stem cells determine their permissiveness for induction of relevant transcriptional changes by SYT-SSX1. PLoS One 2009, 4:e7904.

32. Nagai M, Tanaka S, Tsuda M, Endo S, Kato H, Sonobe H, Minami A, Hiraga $H$, Nishihara H, Sawa H, Nagashima K: Analysis of transforming activity of human synovial sarcoma-associated chimeric protein SYTSSX1 bound to chromatin remodeling factor hBRM/hSNF2 alpha. Proc Natl Acad Sci USA 2001, 98:3843-3848.

33. Francis $P$, Namlos HM, Muller $C$, Eden $P$, Fernebro J, Berner JM, Bjerkehagen B, Akerman M, Bendahl PO, Isinger A, Rydholm A, Myklebost O, Nilbert M: Diagnostic and prognostic gene expression signatures in 177 soft tissue sarcomas: hypoxia-induced transcription profile signifies metastatic potential. BMC Genomics 2007, 8:73.

34. Baird K, Davis S, Antonescu CR, Harper UL, Walker RL, Chen Y, Glatfelter AA, Duray PH, Meltzer PS: Gene expression profiling of human sarcomas: insights into sarcoma biology. Cancer Res 2005, 65:9226-9235.

35. Pretto D, Barco R, Rivera J, Neel N, Gustavson MD, Eid JE: The synovial sarcoma translocation protein SYT-SSX2 recruits beta-catenin to the nucleus and associates with it in an active complex. Oncogene 2006, 25:3661-3669

36. Segal NH, Pavlidis P, Antonescu CR, Maki RG, Noble WS, DeSantis $D$, Woodruff JM, Lewis JJ, Brennan MF, Houghton AN, Cordon-Cardo C Classification and subtype prediction of adult soft tissue sarcoma by functional genomics. Am J Pathol 2003, 163:691-700.

37. Terry J, Saito T, Subramanian S, Ruttan C, Antonescu CR, Goldblum JR, Downs-Kelly E, Corless CL, Rubin BP, van de Rijn M, Ladanyi M, Nielsen TO: TLE1 as a diagnostic immunohistochemical marker for synovial sarcoma emerging from gene expression profiling studies. Am J Surg Pathol 2007, 31:240-246.

38. Jagdis A, Rubin BP, Tubbs RR, Pacheco M, Nielsen TO: Prospective evaluation of TLE1 as a diagnostic immunohistochemical marker in synovial sarcoma. Am J Surg Pathol 2009, 33:1743-1751.

39. Kosemehmetoglu K, Vrana JA, Folpe AL: TLE1 expression is not specific for synovial sarcoma: a whole section study of 163 soft tissue and bone neoplasms. Mod Pathol 2009, 22:872-878.
40. Grbavec D, Stifani S: Molecular interaction between TLE1 and the carboxyl-terminal domain of HES-1 containing the WRPW motif. Biochem Biophys Res Commun 1996, 223:701-705.

41. Su L, Sampaio AV, Jones KB, Pacheco M, Goytain A, Lin S, Poulin N, Yi L, Rossi FM, Kast J, Capecchi MR, Underhill TM, Nielsen TO: Deconstruction of the SS18-SSX fusion oncoprotein complex: insights into disease etiology and therapeutics. Cancer Cell 2012, 21:333-347.

42. Su L, Cheng H, Sampaio AV, Nielsen TO, Underhill TM: EGR1 reactivation by histone deacetylase inhibitors promotes synovial sarcoma cell death through the PTEN tumor suppressor. Oncogene 2010, 29:4352-4361.

43. Barretina J, Taylor BS, Banerji S, Ramos AH, Lagos-Quintana M, Decarolis PL, Shah K, Socci ND, Weir BA, Ho A, Chiang DY, Reva B, Mermel CH, Getz G, Antipin Y, Beroukhim R, Major JE, Hatton C, Nicoletti R, Hanna M, Sharpe T, Fennell TJ, Cibulskis K, Onofrio RC, Saito T, Shukla N, Lau C, Nelander S, Silver SJ, Sougnez C, et al: Subtype-specific genomic alterations define new targets for soft-tissue sarcoma therapy. Nat Genet 2010, 42:715-721.

44. Graziani I, Eliasz S, De Marco MA, Chen Y, Pass HI, De May RM, Strack PR, Miele L, Bocchetta M: Opposite effects of Notch-1 and Notch-2 on mesothelioma cell survival under hypoxia are exerted through the Akt pathway. Cancer Res 2008, 68:9678-9685.

45. Vo K, Amarasinghe B, Washington K, Gonzalez A, Berlin J, Dang TP: Targeting notch pathway enhances rapamycin antitumor activity in pancreas cancers through PTEN phosphorylation. Mol Cancer 2011, 10:138.

46. Wong GW, Knowles GC, Mak TW, Ferrando AA, Zuniga-Pflucker JC: HES1 opposes a PTEN-dependent check on survival, differentiation, and proliferation of TCRbeta-selected mouse thymocytes. Blood 2012, 120:1439-1448

47. Bailis W, Pear WS: Notch and PI3K: how is the road traveled? Blood 2012, 120:1349-1350

48. Staege MS, Hutter C, Neumann I, Foja S, Hattenhorst UE, Hansen G, Afar D, Burdach SE: DNA microarrays reveal relationship of Ewing family tumors to both endothelial and fetal neural crest-derived cells and define novel targets. Cancer Res 2004, 64:8213-8221.

49. May WA, Gishizky ML, Lessnick SL, Lunsford LB, Lewis BC, Delattre O, Zucman J, Thomas G, Denny CT: Ewing sarcoma 11;22 translocation produces a chimeric transcription factor that requires the DNA-binding domain encoded by FLI1 for transformation. Proc Natl Acad Sci USA 1993, 90:5752-5756.

50. Smith R, Owen LA, Trem DJ, Wong JS, Whangbo JS, Golub TR, Lessnick SL: Expression profiling of EWS/FLI identifies NKX2.2 as a critical target gene in Ewing's sarcoma. Cancer Cell 2006, 9:405-416.

51. Baliko F, Bright T, Poon R, Cohen B, Egan SE, Alman BA: Inhibition of notch signaling induces neural differentiation in Ewing sarcoma. Am J Pathol 2007, 170:1686-1694

52. Ban J, Bennani-Baiti IM, Kauer M, Schaefer KL, Poremba C, Jug G, Schwentner R, Smrzka O, Muehlbacher K, Aryee DN, Kovar H: EWS-FLI1 suppresses NOTCH-activated p53 in Ewing's sarcoma. Cancer Res 2008, 68:7100-7109.

53. Beres BJ, George R, Lougher EJ, Barton M, Verrelli BC, McGlade CJ, Rawls JA, Wilson-Rawls J: Numb regulates Notch1, but not Notch3, during myogenesis. Mech Dev 2011, 128:247-257.

54. Bennani-Baiti IM, Aryee DN, Ban J, Machado I, Kauer M, Muhlbacher K, Amann G, Llombart-Bosch A, Kovar H: Notch signalling is off and is uncoupled from HES1 expression in Ewing's sarcoma. J Pathol 2011, 225:353-363.

55. Bennani-Baiti IM, Machado I, Llombart-Bosch A, Kovar H: Lysine-specific demethylase 1 (LSD1/KDM1A/AOF2/BHC110) is expressed and is an epigenetic drug target in chondrosarcoma, Ewing's sarcoma, osteosarcoma, and rhabdomyosarcoma. Hum Pathol 2012, 43:1300-1307.

56. Schildhaus HU, Riegel R, Hartmann W, Steiner S, Wardelmann E, Merkelbach-Bruse S, Tanaka S, Sonobe H, Schule R, Buettner R, Kirfel J: Lysine-specific demethylase 1 is highly expressed in solitary fibrous tumors, synovial sarcomas, rhabdomyosarcomas, desmoplastic small round cell tumors, and malignant peripheral nerve sheath tumors. Hum Pathol 2011, 42:1667-1675.

57. Mulligan P, Yang F, Di Stefano L, Ji JY, Ouyang J, Nishikawa JL, Toiber D, Kulkarni M, Wang Q, Najafi-Shoushtari SH, Mostoslavsky R, Gygi SP, Gill G, Dyson NJ, Naar AM: A SIRT1-LSD1 corepressor complex regulates Notch target gene expression and development. Mol Cell 2011, 42:689-699. 
58. Wang J, Scully K, Zhu X, Cai L, Zhang J, Prefontaine GG, Krones A, Ohgi KA, Zhu P, Garcia-Bassets I, Liu F, Taylor H, Lozach J, Jayes FL, Korach KS, Glass CK, Fu XD, Rosenfeld MG: Opposing LSD1 complexes function in developmental gene activation and repression programmes. Nature 2007, 446:882-887.

59. Di Stefano L, Walker JA, Burgio G, Corona DF, Mulligan P, Naar AM, Dyson NJ: Functional antagonism between histone H3K4 demethylases in vivo. Genes Dev 2011, 25:17-28.

60. Loeb DM, Thornton K, Shokek O: Pediatric soft tissue sarcomas. Surg Clin North Am 2008, 88:615-627, vii.

61. Sorensen PH, Lynch JC, Qualman SJ, Tirabosco R, Lim JF, Maurer HM, Bridge JA, Crist WM, Triche TJ, Barr FG: PAX3-FKHR and PAX7-FKHR gene fusions are prognostic indicators in alveolar rhabdomyosarcoma: a report from the children's oncology group. J Clin Oncol 2002, 20:2672-2679.

62. Davicioni E, Anderson JR, Buckley JD, Meyer WH, Triche TJ: Gene expression profiling for survival prediction in pediatric rhabdomyosarcomas: a report from the children's oncology group. J Clin Oncol 2010, 28:1240-1246.

63. Williamson D, Missiaglia E, de Reynies A, Pierron G, Thuille B, Palenzuela G, Thway K, Orbach D, Lae M, Freneaux P, Pritchard-Jones K, Oberlin O, Shipley J, Delattre O: Fusion gene-negative alveolar rhabdomyosarcoma is clinically and molecularly indistinguishable from embryonal rhabdomyosarcoma. J Clin Oncol 2010, 28:2151-2158.

64. Missiaglia E, Williamson D, Chisholm J, Wirapati P, Pierron G, Petel F, Concordet JP, Thway K, Oberlin O, Pritchard-Jones K, Delattre O, Delorenzi M, Shipley J: PAX3/FOXO1 fusion gene status is the key prognostic molecular marker in rhabdomyosarcoma and significantly improves current risk stratification. J Clin Oncol 2012, 30:1670-1677.

65. Conboy IM, Rando TA: The regulation of Notch signaling controls satellite cell activation and cell fate determination in postnatal myogenesis. Dev Cell 2002, 3:397-409.

66. Conboy IM, Conboy MJ, Smythe GM, Rando TA: Notch-mediated restoration of regenerative potential to aged muscle. Science 2003, 302:1575-1577.

67. Buas MF, Kadesch T: Regulation of skeletal myogenesis by Notch. Exp Cell Res 2010, 316:3028-3033.

68. Sang L, Coller HA, Roberts JM: Control of the reversibility of cellular quiescence by the transcriptional repressor HES1. Science 2008 321:1095-1100

69. Roma J, Masia A, Reventos J, Sanchez de Toledo J, Gallego S: Notch pathway inhibition significantly reduces rhabdomyosarcoma invasiveness and mobility in vitro. Clin Cancer Res 2011, 17:505-513.

70. Belyea BC, Naini S, Bentley RC, Linardic CM: Inhibition of the Notch-Hey1 axis blocks embryonal rhabdomyosarcoma tumorigenesis. Clin Cancer Res 2011, 17:7324-7336.

71. Raimondi L, Ciarapica R, De Salvo M, Verginelli F, Gueguen M, Martini C, De Sio L, Cortese G, Locatelli M, Dang TP, Carlesso N, Miele L, Stifani S, Limon I, Locatelli F, Rota R: Inhibition of Notch3 signalling induces rhabdomyosarcoma cell differentiation promoting p38 phosphorylation and p21(Cip1) expression and hampers tumour cell growth in vitro and in vivo. Cell Death Differ 2012, 19:871-881.

72. Buas MF, Kabak S, Kadesch T: The Notch effector Hey1 associates with myogenic target genes to repress myogenesis. J Biol Chem 2010, 285:1249-1258.

73. Buas MF, Kabak S, Kadesch T: Inhibition of myogenesis by Notch: evidence for multiple pathways. J Cell Physiol 2009, 218:84-93.

74. Ono $Y$, Sensui H, Okutsu S, Nagatomi R: Notch2 negatively regulates myofibroblastic differentiation of myoblasts. J Cell Physiol 2007, 210:358-369.

75. Shukla N, Ameur N, Yilmaz I, Nafa K, Lau CY, Marchetti A, Borsu L, Barr FG, Ladanyi M: Oncogene mutation profiling of pediatric solid tumors reveals significant subsets of embryonal rhabdomyosarcoma and neuroblastoma with mutated genes in growth signaling pathways. Clin Cancer Res 2012, 18:748-757.

76. Nagao H, Setoguchi T, Kitamoto S, Ishidou Y, Nagano S, Yokouchi M, Abematsu M, Kawabata N, Maeda S, Yonezawa S, Komiya S: RBPJ Is a Novel Target for Rhabdomyosarcoma Therapy. PLoS One 2012, 7:e39268.

77. Groth C, Fortini ME: Therapeutic approaches to modulating Notch signaling: Current challenges and future prospects. Semin Cell Dev Biol 2012, 23:465-472.

78. Li K, Li Y, Wu W, Gordon WR, Chang DW, Lu M, Scoggin S, Fu T, Vien L, Histen G, Zheng J, Martin-Hollister R, Duensing T, Singh S, Blacklow SC,
Yao Z, Aster JC, Zhou BB: Modulation of Notch signaling by antibodies specific for the extracellular negative regulatory region of $\mathrm{NOTCH}$. J Biol Chem 2008, 283:8046-8054.

79. Wu Y, Cain-Hom C, Choy L, Hagenbeek TJ, de Leon GP, Chen Y, Finkle D, Venook R, Wu X, Ridgway J, Schahin-Reed D, Dow GJ, Shelton A, Stawicki S, Watts RJ, Zhang J, Choy R, Howard P, Kadyk L, Yan M, Zha J, Callahan CA, Hymowitz SG, Siebel CW: Therapeutic antibody targeting of individual Notch receptors. Nature 2010, 464:1052-1057.

80. Ridgway J, Zhang G, Wu Y, Stawicki S, Liang WC, Chanthery Y, Kowalski J, Watts RJ, Callahan C, Kasman I, Singh M, Chien M, Tan C, Hongo JA, de Sauvage F, Plowman G, Yan M: Inhibition of Dll4 signalling inhibits tumour growth by deregulating angiogenesis. Nature 2006, 444:1083-1087.

81. Moellering RE, Cornejo M, Davis TN, Del Bianco C, Aster JC, Blacklow SC, Kung AL, Gilliland DG, Verdine GL, Bradner JE: Direct inhibition of the NOTCH transcription factor complex. Nature 2009, 462:182-188.

82. Murakami D, Okamoto I, Nagano O, Kawano Y, Tomita T, Iwatsubo T, De Strooper B, Yumoto E, Saya H: Presenilin-dependent gamma-secretase activity mediates the intramembranous cleavage of CD44. Oncogene 2003, 22:1511-1516.

83. van Es JH, van Gijn ME, Riccio O, van den Born M, Vooijs M, Begthel $H$, Cozijnsen M, Robine S, Winton DJ, Radtke F, Clevers H: Notch/gammasecretase inhibition turns proliferative cells in intestinal crypts and adenomas into goblet cells. Nature 2005, 435:959-963.

84. Riccio O, van Gijn ME, Bezdek AC, Pellegrinet L, van Es JH, Zimber-Strobl U, Strobl LJ, Honjo T, Clevers H, Radtke F: Loss of intestinal crypt progenitor cells owing to inactivation of both Notch1 and Notch2 is accompanied by derepression of CDK inhibitors p27Kip1 and p57Kip2. EMBO Rep 2008, 9:377-383.

85. Harrison H, Farnie G, Howell SJ, Rock RE, Stylianou S, Brennan KR, Bundred NJ, Clarke RB: Regulation of breast cancer stem cell activity by signaling through the Notch4 receptor. Cancer Res 2010, 70:709-718.

86. Extance A: Alzheimer's failure raises questions about disease-modifying strategies. Nat Rev Drug Discov 2010, 9:749-751.

87. Fouladi M, Stewart CF, Olson J, Wagner LM, Onar-Thomas A, Kocak M, Packer RJ, Goldman S, Gururangan S, Gajjar A, Demuth T, Kun LE, Boyett JM, Gilbertson RJ: Phase I trial of MK-0752 in children with refractory CNS malignancies: a pediatric brain tumor consortium study. J Clin Oncol 2011, 29:3529-3534.

88. Krop I, Demuth T, Guthrie T, Wen PY, Mason WP, Chinnaiyan P, Butowski N, Groves MD, Kesari S, Freedman SJ, Blackman S, Watters J, Loboda A, Podtelezhnikov A, Lunceford J, Chen C, Giannotti M, Hing J, Beckman R, Lorusso P: Phase I pharmacologic and pharmacodynamic study of the gamma secretase (Notch) inhibitor MK-0752 in adult patients with advanced solid tumors. J Clin Oncol 2012, 30:2307-2313.

89. Albain KS, Czerlanis C, Zlobin A, Covington KR, Rajan P, Godellas C, Bova D, Lo SS, Robinson P, Sarker S, Gaynor ER, Cooper R, Aranha G, Czaplicki K, Busby B, Rizzo P, Demuth T, Stiff P, Fuqua SAW, Miele L: Modulation of Cancer and Stem Cell Biomarkers by the Notch Inhibitor MK-0752 Added to Endocrine Therapy for Early Stage ER+ Breast Cancer. Cancer Res 2012, 71:S1-5, 24_MeetingAbstracts.

90. Rizzo P, Miao H, D'Souza G, Osipo C, Song LL, Yun J, Zhao H, Mascarenhas J, Wyatt D, Antico G, Hao L, Yao K, Rajan P, Hicks C, Siziopikou K, Selvaggi S, Bashir A, Bhandari D, Marchese A, Lendahl U, Qin JZ, Tonetti DA, Albain K, Nickoloff BJ, Miele L: Cross-talk between notch and the estrogen receptor in breast cancer suggests novel therapeutic approaches. Cancer Res 2008, 68:5226-5235.

91. Hao L, Rizzo P, Osipo C, Pannuti A, Wyatt D, Cheung LW, Sonenshein G, Osborne BA, Miele L: Notch-1 activates estrogen receptor-alphadependent transcription via IKKalpha in breast cancer cells. Oncogene 2010, 29:201-213.

92. Luistro L, He W, Smith M, Packman K, Vilenchik M, Carvajal D, Roberts J, Cai J, Berkofsky-Fessler W, Hilton H, Linn M, Flohr A, Jakob-Rotne R, Jacobsen H, Glenn K, Heimbrook D, Boylan JF: Preclinical profile of a potent gamma-secretase inhibitor targeting notch signaling with in vivo efficacy and pharmacodynamic properties. Cancer Res 2009, 69:7672-7680.

93. Tolcher AW, Messersmith WA, Mikulski SM, Papadopoulos KP, Kwak EL, Gibbon DG, Patnaik A, Falchook GS, Dasari A, Shapiro Gl, Boylan JF, Xu ZX, Wang K, Koehler A, Song J, Middleton SA, Deutsch J, Demario M, Kurzrock R, Wheler JJ: Phase I study of RO4929097, a gamma secretase 
inhibitor of Notch signaling, in patients with refractory metastatic or locally advanced solid tumors. J Clin Oncol 2012, 30:2348-2353.

94. Strosberg JR, Yeatman T, Weber J, Coppola D, Schell MJ, Han G, Almhanna K, Kim R, Valone T, Jump H, Sullivan D: A phase II study of RO4929097 in metastatic colorectal cancer. Eur J Cancer 2012, 48:997-1003.

95. Pandya K, Meeke K, Clementz AG, Rogowski A, Roberts J, Miele L, Albain KS, Osipo C: Targeting both Notch and ErbB-2 signalling pathways is required for prevention of ErbB-2-positive breast tumour recurrence. $\mathrm{Br} J$ Cancer 2011, 105:796-806.

96. Aster JC, Blacklow SC: Targeting the notch pathway: twists and turns on the road to rational therapeutics. J Clin Oncol 2012, 30:2418-2420.

\section{Pre-publication history}

The pre-publication history for this paper can be accessed here: http://www.biomedcentral.com/1741-7015/10/141/prepub

doi:10.1186/1741-7015-10-141

Cite this article as: Rota et al: Notch signaling in pediatric soft tissue sarcomas. BMC Medicine 2012 10:141.

\section{Submit your next manuscript to BioMed Central} and take full advantage of:

- Convenient online submission

- Thorough peer review

- No space constraints or color figure charges

- Immediate publication on acceptance

- Inclusion in PubMed, CAS, Scopus and Google Scholar

- Research which is freely available for redistribution

Submit your manuscript at www.biomedcentral.com/submit 